\title{
A INCONSTITUCIONALIDADE DO ART. 1.790 DO CÓDIGO CIVIL: REFLEXÓES SOBRE A DECISÃO DO SUPREMO TRIBUNAL FEDERAL FRENTE AOS PRINCÍPIOS DA LIBERDADE E DA AUTONOMIA PRIVADA
}

\author{
THE UNCONSTITUTIONALITY OF ART. 1.790 OF THE CIVIL CODE: \\ REFLECTIONS ON THE DECISION OF THE SUPREME FEDERAL \\ COURT REGARDING THE PRINCIPLES OF FREEDOM AND PRIVATE \\ AUTONOMY
}

\author{
Luciane Sobral ${ }^{\mathrm{I}}$ (i) \\ Marco Antonio Lima Berberi ${ }^{\mathrm{II}}$ (i)
}

\footnotetext{
${ }^{\mathrm{I}}$ Centro Universitário Autônomo do Brasil, Curitiba, PR, Brasil.

Mestranda em Direitos Fundamentais e Democracia. E-mail: lucianesobral.adv@ gmail.com

${ }^{\text {II }}$ Centro Universitário Autônomo do Brasil, Curitiba, PR, Brasil. Doutor em Direito. E-mail: marcoberberi@gmail.com
}

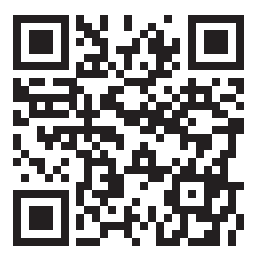

DOI: http://dx.doi.org/10.31512/rdj.v20i38.146

Recebido em: 22.12.2018

Aceito em: 05.04.2020
Resumo: O presente artigo visa analisar, com foco nos princípios da liberdade e da autonomia privada, o teor da decisão tomada pelo Supremo Tribunal Federal (RE 878.694/MG) que equiparou companheiro e cônjuge para fins sucessórios ao considerar o art. 1.790 da legislação civil inconstitucional. A metodologia de pesquisa utilizada se deu através do método hipotético-dedutivo, por meio de pesquisa documental junto ao Acórdão do Recurso Extraordinário julgado e baseado na análise doutrinária a respeito dos institutos abordados. Dentre os resultados alcançados, destaca-se a diferença dos institutos da união estável e do casamento e o foco aos princípios da liberdade e autonomia privada como garantidores da segurança jurídica, já que a lei previa consequências sucessórias distintas para cada uma das entidades familiares.

Palavras-chave: Casamento. União estável. Sucessões.

Abstract: This article aims to analyze, based on the principles of freedom and private autonomy, the content of the decision taken by the Federal Supreme Court (RE 878.694/ $\mathrm{MG}$ ) that equated partner and spouse for inheritance purposes considering unconstitutional the article 1.790 of the civil legislation. The research methodology used was the hypothetical-deductive method, documentary research of the Extraordinary Appeal Judgment judged and based on the doctrinal analysis regarding the institutes addressed. Among the results achieved, it is highlighted the difference between the institutes of the common-law marriage and marriage itself and the focus on the principles of freedom and private autonomy as guarantors of legal security, as the law had different succession consequences for each of the family entities.

Keywords: Marriage. Common-law marriage. Succession. 


\section{Consideraçóes iniciais}

As famílias estão em constante evolução e o Direito das Famílias, por sua vez, procura acompanhar tal evoluçáo. Assim aconteceu quando a uniáo estável passou a ser reconhecida no ordenamento jurídico brasileiro, por força da Constituição Federal.

Posteriormente, o atual Código Civil tratou das consequências jurídicas da união estável e estabeleceu diferenças entre essa forma de constituição de família e a constituição pelo casamento. Especificamente com relação às consequências sucessórias, tratou sobre a sucessão do companheiro e a sucessão do cônjuge nos artigos 1.790 e 1.829 , respectivamente.

Em maio de 2017, o Supremo Tribunal Federal foi questionado acerca da inconstitucionalidade do art. 1.790, do Código Civil, dispositivo que versa sobre as questóes sucessórias do companheiro. No caso levado a julgamento, o falecido não tinha descendentes ou ascendentes, apenas a companheira e irmãos; considerando que o casal constituiu uma união estável de fato, as consequências sucessórias aplicadas à companheira não lhe foram satisfatórias, visto que pleiteou os mesmos direitos que teria se casada fosse.

Nesse sentido, por meio do método hipotético-dedutivo, realizado pela análise dos votos do julgamento do RE n. 878.694/MG e com base no entendimento doutrinário sobre o tema, o presente artigo busca verificar se os princípios da liberdade e da autonomia privada foram levados em consideração na decisão que equiparou cônjuge e companheiro para efeitos sucessórios.

Assim sendo, o presente artigo (i) tratará das principais diferenças entre casamento e união estável; (ii) analisará os votos dos Ministros no julgado em questão, tanto o do Relator quanto o Divergente, bem como a argumentação utilizada pelos Ministros e, por fim, (iii) analisará os princípios da liberdade e da autonomia privada e sua relação com as questóes emocionais vivenciadas pelos casais na escolha da melhor forma de constituição de família.

\section{Casamento e união estável}

A formação de uma família pode ocorrer de várias maneiras e por meio de diferentes institutos, dentre eles, o mais antigo e tradicional é o casamento. A família constituída a partir do casamento denomina-se "família matrimonial" e a proteção nele investida se dá exatamente em virtude das formalidades estabelecidas (CARVALHO, 2015, p. 151-152). De outro lado, não há no Código Civil conceituação de "casamento" ou "família", tendo, no entanto, o legislador tratado de requisitos, finalidade, direitos e deveres dos cônjuges e definido a questáo patrimonial (DIAS, 2015, p. 146). 
Assim sendo, a formulação do conceito de família se deu pela doutrina. Por todos, Venosa (2011, p. 25):

O casamento é o centro do direito de família. Dele irradiam suas normas fundamentais. Sua importância, como negócio jurídico formal, vai desde as formalidades que antecedem sua celebração, passando pelo ato material de conclusão até os efeitos do negócio que deságuam nas relaçôes entre os cônjuges, os deveres recíprocos, a criação e a assistência material e espiritual recíproca e da prole.

O formalismo atribuído a esta modalidade de constituição de família é visível em nosso Código Civil, eis que o primeiro "Subtítulo" trazido pelo Livro do Direito de Família é o do casamento, regido pelos arts.1.517 a 1.590 do Código Civil.

O casamento - ainda que a legislação não lhe dê uma definição específica - gera um "estado matrimonial”, cuja finalidade está disposta no art. 1.511 do Código Civil, qual seja, o estabelecimento de comunhão plena de vida com base na igualdade de direitos e deveres dos cônjuges. Também, atribui seus efeitos, pois prevê encargos e ônus dele decorrentes, v.g. o art. 1.565 do Código Civil, que dispóe sobre a mútua responsabilidade dos cônjuges com relação aos encargos da família (DIAS, 2015, p. 147).

Tem-se, portanto, que o casamento é um dos arranjos familiares existentes no ordenamento jurídico brasileiro, pelo qual se estabelece vínculo conjugal entre as partes e, por via de consequência, a constituição de uma família.

Em sua concepçáo, há direitos e deveres a serem observados pelos cônjuges, dentre eles igualdade e mútua assistência. Indo além, percebe-se a relevância do aspecto patrimonial, visto que casamento é sinônimo de comunhão de vidas e, na maioria das vezes, comunhão de patrimônio também ${ }^{1}$.

A união estável, por sua vez, é outro arranjo familiar existente no ordenamento jurídico, que passou a ser reconhecida formalmente com a alteração do art. 226, $\$ 3^{\circ}$, da Constituição Federal e, posteriormente, por meio do art. 1.723 do Código Civil. Entretanto, trabalhar o conceito de uniâo estável é um dos desafios do Direito das Famílias contemporâneo (DIAS, 2015, p. 241). Sua definição doutrinária pode assim ser trabalhada:

A união estável é a entidade familiar constituída por duas pessoas que convivem em posse do estado de casado, ou com aparência de casamento (more uxorio). É um estado de fato que se converteu em relação jurídica em virtude de a Constituição e a lei atribuírem-lhe dignidades de entidade familiar própria, com seus elencos direitos e deveres. Ainda que o casamento seja sua referência estrutural, é distinta deste; cada entidade é dotada de estatuto jurídico próprio, sem hierarquia ou primazia. (LÔBO, 2014, p. 150).

$\mathrm{O}$ art. 226, da Constituição Federal, o art. 1.723, do Código Civil e a decisão do Supremo Tribunal Federal na ADI 4.277/2011 estabelecem os requisitos legais da união estável: a) relação afetiva entre os companheiros; b) convivência pública, contínua 
e duradoura; c) objetivo de constituição de família; d) possibilidade de conversão para o casamento (LÔBO, 2014, p. 153).

Assim sendo, casamento e união estável são formas diferentes de constituição de família, isto é, arranjos familiares distintos, cada qual com suas particularidades:

O marco sinalizador do estado civil sempre foi o casamento. Nem é preciso repetir que a uniáo estável e o casamento são institutos distintos, mas as sequelas de ordem patrimonial identificam-se. Com o casamento ocorre a alteração do estado civil dos noivos, que passam à condição de casados. Já a união estável, em geral, não tem um elemento objetivo definindo seu início, mas nem por isso deixa de produzir consequências jurídicas desde a sua constituição. (DIAS, 2015, p. 246)

Uma das características da união estável é a desnecessidade de documentar a família constituída, diferente do que ocorre com o casamento; a uniáo estável é reconhecida independentemente de sua formalização mediante escritura pública que declare seu início. Em virtude dessa informalidade, é necessário tomar cuidado para não confundila com um simples namoro, já que a convivência sob o mesmo teto e o período que o casal está junto não são requisitos imprescindíveis para caracterização da união estável. Em virtude disso, tem-se o chamado "contrato de namoro", em que as partes pactuam que a relação existente entre elas é tão somente de namorados e não de companheiros, exercendo a liberdade disciplinada pela Constituição Federal. Porém, a eficácia do contrato de namoro não é garantida:

Todavia, considerando que a relação jurídica da união estável é ato-fato jurídico, cujos efeitos independem da vontade das pessoas envolvidas, esse contrato é de eficácia limitada, apenas servindo como elemento de prova, que pode ser desmentida por outras provas. (LÔBO, 2014, p. 157).

Assim sendo, parte-se do pressuposto de que existindo dois institutos diversos para a constituição de uma família, o casal possui a liberdade e autonomia em optar por qual lhes é mais interessante, observando suas características e consequências.

No entanto, mesmo afirmando as diferenças existentes entre cada instituto, há doutrina que defende a necessidade de equiparação de suas consequências:

Sempre que o legislador deixa de nominar a união estável frente a prerrogativas concedidas ao casamento, outorgando-lhe tratamento diferenciado, a omissão deve ser tida por inexistente, ineficaz e inconstitucional. Do mesmo modo, em todo texto em que é citado o cônjuge é necessário ler-se cônjuge ou companheiro. (DIAS, 2015, p. 242).

Partindo do entendimento, comungado por vários autores ${ }^{2}$, que é necessária uma readequação da lei, de modo a estender os direitos e deveres dos cônjuges aos

2 Dentre tantos, destaca-se Rolf Madaleno (MADALENO, 2019, p.4), Maria Berenice Dias, Rodrigo da Cunha Pereira e Ana Luiza Maia Nevares (IBDFAM. Embargos de Declaração opostos no RE 878.694/MG. Disponível em: <http://ibdfam.org.br/assets/img/upload/files/Peti\%C3\%A7\%C3\%A3o\%20Embargos.pdf> Acesso em 27 jul. 2019). 
companheiros, é que se analisa a decisão do Supremo Tribunal Federal que trata das questôes sucessórias e a posição do cônjuge e do companheiro.

\section{A decisão do Supremo Tribunal Federal no julgamento do recurso extraordinário no 878.694/MG}

\subsection{Do voto relator}

Foi reconhecida a repercussão geral do Recurso Extraordinário no 878.694/MG para análise da constitucionalidade do art. 1.790, do Código Civil, tendo em vista a distinção dos direitos sucessórios garantidos ao companheiro em comparaçáo aos do cônjuge, disciplinado pelo art. 1.829, do Código Civil.

$\mathrm{O}$ caso em análise diz respeito ao patrimônio do falecido, o qual não deixou descendentes ou ascendentes, mas apenas a companheira - com a qual convivia há cerca de 9 anos - e irmãos. Em atendimento ao precitado art. 1.790, a companheira teria direito a $1 / 3$ dos bens adquiridos onerosamente durante a união estável, excluindo-se os bens particulares do falecido, os quais seriam recebidos, como herança, pelos irmãos.

O Relator, Ministro Luís Roberto Barroso, após abordar o histórico e a evolução do Direito das Famílias, destacou o reconhecimento da união estável no âmbito jurídico, inicialmente caracterizado pela indenizaçáo por serviços prestados durante a sociedade de fato constituída (como era anteriormente denominada) e, posteriormente, por força da Constituição Federal, que estabeleceu que a união estável também seria uma forma legítima de constituição de família. Destaca, ainda, que o princípio da dignidade da pessoa humana foi o ponto fundamental para essa gradativa ressignificação da família. Em relação aos direitos sucessórios, aponta novamente a importância da Constituiçáo Federal como base de proteção da família e passa a analisar as diferenças entre os regimes sucessórios a partir do Código Civil.

A primeira diferença diz respeito à restrição da participação hereditária do companheiro aos bens adquiridos onerosamente na vigência da uniáo estável, diferente da regra aplicada ao cônjuge, já que em relação a esses bens o companheiro já teria direito à meação; de acordo com o art. 1.790 do Código Civil, estão excluídos da sucessão do companheiro qualquer bem adquirido gratuitamente pelo falecido ou onerosamente antes da vigência da união estável.

A segunda diferença apontada pelo Relator se liga à ordem de vocação hereditária; nos casos em que o companheiro tem direito à sucessão, seu quinhão é muito inferior ao que lhe seria conferido se fosse casado com o falecido. Destaca que no caso analisado, como o falecido possuía três irmãos, a companheira teria direito apenas a $1 / 3$ dos bens 
adquiridos onerosamente durante a vigência da união, mas caso fosse casada com o falecido, teria direito a todo o monte sucessório.

Por outro lado, fez constar em seu voto exemplos de algumas situaçóes em que as questôes sucessórias dispostas no Código Civil colocam a união estável em situação privilegiada em relaçáo ao casamento. Traz o caso exemplificativo do de cujus que, em vida, constituiu todos os bens onerosamente durante a uniáo estável e, ao falecer, tenha deixado descendentes comuns; o regime de bens adotado entre os companheiros poderia ser o da comunhão parcial, comunhão universal ou separação obrigatória de bens e, de qualquer forma, o companheiro teria direito a uma quota equivalente a por lei atribuída a cada filho comum, nos termos do art. 1.790, I, do Código Civil. No entanto, caso fossem casados, o cônjuge não teria direito a participar da sucessão, nos termos do art. 1.829, I, do Código Civil e, portanto, nada herdaria.

Veja-se o teor dos dispositivos mencionados:

Art. 1.790. A companheira ou o companheiro participará da sucessão do outro, quanto aos bens adquiridos onerosamente na vigência da união estável, nas condiçóes seguintes:

I - se concorrer com filhos comuns, terá direito a uma quota equivalente à que por lei for atribuída ao filho. (BRASIL, Código Civil 2002).

Art. 1.829. A sucessão legítima defere-se na ordem seguinte:

I - aos descendentes, em concorrência com o cônjuge sobrevivente, salvo se casado este com o falecido no regime da comunhão universal, ou no da separação obrigatória de bens (art. 1.640, parágrafo único); ou se, no regime da comunhão parcial, o autor da herança não houver deixado bens particulares. (BRASIL, Código Civil 2002).

Referido exemplo fora trazido pelo Relator a fim de demonstrar que, caso o propósito do legislador tenha sido colocar o casamento em um patamar superior à uniáo estável, este objetivo não foi alcançado, visto que há situaçôes em que o companheiro é beneficiado em relação ao cônjuge.

Na sequência, ao analisar o texto do art. 226, da Constituição Federal, pontuou a existência de três formas de estabelecimento de arranjo familiar: casamento, união estável e família monoparental.

Destacou, ainda, que "está implícita nesta cláusula (parte final do $\$ 3^{\circ}$, do art. 226) a possibilidade de o legislador infraconstitucional traçar contornos distintos para as duas entidades familiares.", ou seja, casamento e união estável são diferentes formas de constituição de família já que há, inclusive, disposição de que a lei deve facilitar a conversão da união estável em casamento. Apesar da distinção, entende, do ponto de vista da funcionalização da família, que:

Só será legítima a diferenciação de regimes entre casamento e união estável se não implicar hierarquização de uma entidade familiar em relação à outra, desigualando o nível de proteção estatal conferido aos indivíduos. (BARROSO, 2017, trecho do voto). 
Afirma, ainda, que "se a diferenciação entre os regimes basear-se em circunstâncias inerentes às peculiaridades de cada tipo de entidade familiar, tal distinção será perfeitamente legítima”. (BARROSO, trecho do voto). Deve-se apenas tomar cuidado se a diferenciação é arbitrária ou não.

Por fim, o Relator concluiu pela inconstitucionalidade da distinção de regimes sucessórios entre cônjuges e companheiros prevista no art. 1.790, do Código Civil, devendo ser aplicado o disposto no art. 1.829, do Código Civil para cônjuges e companheiros.

\subsection{Dos votos que acompanharam o relator}

Ao fundamentar seu voto - que acompanhou integralmente o voto do Relator -, o Ministro Luiz Edson Fachin considerou que a aplicação de dispositivos diferentes para casamento e união estável quanto à sucessão seria "tratar de modo diferente pessoas em igual situação - conjugalidade lato sensu, originada na coexistência em comunhão de vida”, já que "os quinhóes do companheiro sobrevivente sobre o acervo passível de concorrência sucessória são sempre inferiores àqueles atribuídos aos casados" (FACHIN, trecho do voto).

O Ministro Teori Zavascki asseverou que quando atuou no STJ entendeu certa feita pela constitucionalidade do dispositivo, mas reconheceu neste julgamento que mudou seu posicionamento, de modo que acompanhou o voto do Relator e do Ministro Edson Fachin.

O Ministro Celso de Mello acompanhou o Relator, afirmando que a declaraçáo de inconstitucionalidade do dispositivo em questão estaria por "viabilizar a plena realização dos valores da liberdade, da igualdade e da não discriminação (...) tornando efetivo, assim, o princípio da isonomia, assegurando o respeito à liberdade pessoal e à autonomia individual" (MELLO, trecho do voto).

Os Ministros Rosa Weber, Luiz Fux e Carmen Lúcia igualmente acompanharam o voto do Relator.

\subsection{Do voto-vista (voto divergente)}

Náo convencido pelos argumentos do Relator e dos colegas que o acompanharam, o Ministro Dias Toffoli fez pedido de vistas asseverando que a Constituiçáa protege a união estável, mas jamais dá a entender que união estável é casamento. Fez ainda uma reflexão antes de analisar a fundo o caso: "minha grande preocupação aqui é nós estarmos anulando a autonomia da vontade" (TOFFOLI, trecho do voto).

$\mathrm{Na}$ redação do voto divergente, percebe-se que a argumentação é lastreada em análise específica da autonomia de vontade e do princípio da liberdade, como se verá especificamente no tópico subsequente. 
Corroborando o entendimento do Ministro a respeito dos princípios constitucionais que merecem atenção, tem-se importante observação sobre colisão entre princípios constitucionais:

A colisão entre princípios constitucionais não tem solução no campo da validade, mas sim no âmbito do valor. Se uma determinada situação é proibida, mas permitida por outro, não há que se falar em nulidade do primeiro pela aplicação do outro ou viceversa. No caso concreto, em uma relação de procedência condicionada, determinado princípio terá maior relevância que outro, preponderando segundo as circunstâncias fáticas e jurídicas. (CRISTÓVAM, 2016, p. 252).

Assim, ao contrário daqueles que votaram pela inconstitucionalidade do dispositivo infraconstitucional, o Ministro Dias Toffoli se ateve aos princípios da liberdade e da autonomia privada, indagando se o fato de declarar inconstitucional um artigo que trata das consequências sucessórias da união estável causaria ou não um impacto em referidos princípios constitucionais, já que, ao que tudo indica, o Relator e os demais que o acompanharam preocuparam-se especialmente com o princípio da igualdade, a fim de aplicar a mesma regra para cônjuge e companheiro.

\subsection{Voto acompanhando a divergência}

Acompanhando o voto divergente, o Ministro Marco Aurélio Farias Mello fez ponderaçóes importantes a fim de justificar seu posicionamento:

É temerário igualizar regimes familiares, a repercutir nas relaçóes sociais, desconsiderando, por completo, o ato de vontade direcionado à constituição de específica entidade familiar que a Carta da República prevê distinta, inconfundível com o casamento e, portanto, a própria autonomia dos indivíduos de como melhor conduzir a vida a dois (FARIAS MELLO, 2017, trecho do voto).

Ao que tudo indica, a divergência entre os votos está no olhar que se deu aos institutos formadores de família: enquanto alguns entendem que a opção do casal deve ser feita analisando as consequências jurídicas de cada instituto - que inclusive pode ser objeto de um planejamento patrimonial e sucessório -, outros entendem que a igualdade deve prevalecer entre os casais que optaram pela união estável e os que optaram pelo casamento.

O Ministro Marco Aurélio Farias Mello observou que, ao declarar a inconstitucionalidade do dispositivo que estabelece diferenças sucessórias entre os institutos, estar-se-ia desrespeitando a liberdade do casal:

Entender de modo diverso, igualando casamento e união estável, em especial no tocante ao direito sucessório, significa, além do prejuízo para os sucessores, desrespeitar a autonomia do casal, quando da opção entre os institutos, em eleger aquele que melhor atendesse à pretensão de constituição do núcleo familiar - casamento ou união estável (FARIAS MELLO, 2017, trecho do voto). 
Seguindo na argumentação, entende o Ministro que o Poder Judiciário, ao interferir nas questóes particulares dos indivíduos, acaba violando princípios fundamentais que contribuem para a formação do arcabouço do Estado Democrático de Direito:

Não cabe ao Judiciário, após a escolha legítima pelos particulares, sabedores das consequências, suprimir a manifestaçáo de vontade com promoçáo de equiparaçóes, sob pena de ter-se manifesta violação a um dos pilares do Estado Democrático de Direito - o direito à liberdade, à autodeterminação (FARIAS MELLO, 2017, trecho do voto).

Revela, ainda, preocupação com a segurança jurídica, ao se permitir aplicar após a morte do indivíduo algo diverso daquilo que escolheu em vida:

Não há como afirmar que o companheiro falecido aderiria a regime jurídico diverso do alusivo à união estável, surgindo incompatível com a autodeterminação da pessoa a revisão após o óbito (FARIAS MELLO, 2017, trecho do voto).

Por fim, o Ministro Marco Aurélio Farias Mello acompanha o Ministro Dias Toffoli, que levantou a divergência, pelo não provimento do Recurso Extraordinário, a fim de declarar constitucional o regime sucessório previsto no art. 1.790, do Código Civil.

\section{Princípios constitucionais da liberdade e autonomia privada e as questóes emocionais envolvidas}

$\mathrm{Na}$ análise feita do julgado do Supremo Tribunal Federal, percebe-se que em muitos momentos, em especial na fundamentação do mérito da decisão que entendeu pela inconstitucionalidade do art. 1.790, do Código Civil, há menção aos princípios constitucionais da igualdade e da dignidade da pessoa humana:

A consagração da dignidade da pessoa humana como valor central do ordenamento jurídico e como um dos fundamentos da República brasileira (art. 1º, III, CF/1988) foi o vetor e o ponto de virada para essa gradativa ressignificação da família. (BARROSO, 2017, trecho do voto).

Em seu voto, o Relator entende que o art. 1.790, do Código Civil, viola o princípio da dignidade da pessoa humana e indica o que se contempla no referido princípio:

(1) o valor intrínseco de todos os seres humanos; (2) a autonomia de cada indivíduo; (3) limitada por algumas restriçôes legítimas impostas a ela em nome de valores sociais ou interesses estatais" (BARROSO, 2012, p. 127).

A Procuradoria-Geral da República, por sua vez, emitiu parecer pelo não provimento do recurso, com fundamento na autonomia privada dos contraentes e a liberdade em escolher uma formação de família sem regras rígidas. Segue trecho do relatório do julgado com posicionamento da Procuradoria-Geral da República acerca da opção entre casamento e união estável e suas regras: 
Tanto a união estável quanto o casamento constituem manifestaçáo da autonomia privada dos contraentes, pois, se não há impedimento para o casamento e, mesmo assim, os conviventes optam pela união estável, é porque a entendem mais adequada às suas necessidades e anseios, ou, ainda, por preferirem ficar livres das regras rígidas impostas pelo casamento (BARROSO, 2017, trecho do relatório do acórdáo).

O Relator entende que, apesar da autonomia privada estar presente na opção do indivíduo de constituir uma família, o Código Civil a restringe ao criar regimes sucessórios diversos para casamento e união estável. Entende, ainda, que deveria o Estado prever um regime sucessório impositivo, conforme trecho do voto:

Em verdade, a ideia de se prever em lei um regime sucessório impositivo parte justamente da concepção de que, independentemente da vontade do indivíduo em vida, o Estado deve fazer com que ao menos uma parcela de seu patrimônio seja distribuída aos familiares mais próximos no momento de sua morte, de modo a garantir meios de sustento para o núcleo familiar. E não faz sentido desproteger o companheiro na sucessão legítima apenas porque não optou pelo casamento. $\mathrm{O}$ fato de as uniōes estáveis ocorrerem com maior frequência justamente nas classes menos favorecidas e esclarecidas da população apenas reforça o argumento da impossibilidade de distinguir tais regimes sucessórios, sob pena de prejudicar justamente aqueles que mais precisam da proteçáo estatal e sucessória (BARROSO, 2017, trecho do voto).

Traz ainda argumentação sobre o princípio da proporcionalidade e sua violação como vedação à proteção deficiente do Estado, afirmando que "não se pode defender uma preferência constitucional ao casamento para justificar a manutenção da norma do Código Civil menos protetiva da união estável em relação ao regime sucessório aplicável" (BARROSO, 2017, trecho do voto). Nesse sentido, interessante o seguinte raciocínio:

Restringir a incidência do direito sucessório do companheiro sobrevivente aos bens adquiridos pelo de cujos na vigência da união estável não tem nenhuma razão, não tem lógica alguma, e quebra todo o sistema, podendo gerar consequências extremamente injustas: a companheira de muitos anos de um homem rico, que possuía vários bens na época em que iniciou o relacionamento afetivo, não herdará coisa alguma do companheiro, se este não adquiriu outros bens durante o tempo da convivência. Ficará esta mulher - se for pobre - literalmente desamparada, mormente quando o falecido não cuidou de beneficiá-la em testamento, ou foi surpreendido pela morte antes de outorgar o testamento que havia resolvido fazer. (PEREIRA, 2002, p. 281/282).

No exemplo acima trazido, a análise feita pelo autor merece questionamento. Ao lado da indagação sobre o eventual desemparo da companheira sobrevivente, tem-se que considerar a possibilidade de o falecido não ter desejado compartilhar seus bens com ela, bem como o fato de não terem adquirido bens em conjunto. Se a opção fora realmente a união estável, observando as consequências sucessórias e até mesmo patrimoniais - num caso de separação em vida entre eles - verifica-se a importância do respeito à liberdade e à autonomia privada exercida em vida pelo de cujus. Como se está a fazer conjecturas, todas devem ser consideradas. 
Exame acerca da violação ao princípio da vedação ao retrocesso, princípio constitucional implícito, foi feito pelo Relator como forma de fundamentar que as leis 8.971/1994 e 9.278/1996 que versavam sobre os companheiros antes da vigência do Código Civil já indicavam equiparação de direitos entre cônjuge e companheiro. Assim, qualquer movimento legislativo no sentido de garantir o exercício da autonomia privada pelos companheiros não pode negar a equiparação dos regimes sucessórios do casamento e da união estável:

É importante observar, porém, que a declaração de inconstitucionalidade da distinção de regimes sucessórios entre cônjuges e companheiros, prevista no art. 1.790 do Código Civil, não impede uma futura atuação do legislador no sentido de garantir a possibilidade de exercício da autonomia da vontade pelos companheiros (e também pelos cônjuges). Desde que mantenha a equiparação de regimes sucessórios entre o casamento e a união estável como regra geral, o Poder Legislativo poderá criar regime sucessório diverso, ao qual os companheiros poderão optar, em vida, mediante acordo escrito (BARROSO, 2017, trecho do voto).

É interessante, no entanto, destacar o fato de que, mesmo havendo distinção entre os institutos, os seus efeitos e consequências se tornaram iguais, ou seja, os casais que desejam simplesmente uma união sem qualquer formalidade, divisão de bens ou quinhão para fins de sucessão (seja porque já houve outros casamentos, seja porque não desejam compartilhar entre si os bens), terão que pactuar formalmente o que desejam para fins sucessórios, correndo o risco ainda de náo conseguirem em morte os efeitos que desejam.

Imperioso lembrar que no Direito das Famílias, junto aos princípios da liberdade e da autonomia privada, estão presentes questóes de ordem psicológica e emocional; muito antes de serem atribuídos encargos aos cônjuges ou companheiros, quanto ao patrimônio e sua gestão, há o envolvimento emocional do casal. Tem que o principal motivo que leva o casal a estabelecer uma vida em conjunto, na maioria das vezes, é sentimento denominado "amor":

$\mathrm{Na}$ íntima relação entre direito e amor, que acreditamos existir de forma quase atávica, vemos que no campo das relaçôes pessoais a formação da família e a filiação se descortinam como os exemplos mais marcantes. (MALUF, 2012, p.8).

Destaca-se, ainda, a dificuldade de separar a "razão da emoção", especialmente quando o casal está passando por uma fase de preparação para a uniáo, em que ambos estão em momento profundamente emocional:

É enorme a dificuldade de falar em questóes patrimoniais, separação, divórcio e morte quando se está vivendo um grande amor. Prever a sua finitude gera ressentimentos, medo e insegurança, como se estivesse sendo posta em dúvida a eternidade das juras feitas. Até parece mau agouro em momento de pura alegria e felicidade. Afinal, o afeto é tâo intenso que as pessoas desejam viver juntas para sempre. (DIAS, 2009, p. 27). 
O que não se pode, entretanto, é generalizar e retirar a liberdade do casal de escolher a melhor forma de se unirem ou do regime de bem a ser escolhido. São visíveis as diferenças entre o casamento e a união estável, em que o primeiro, para se realizar, necessita do cumprimento de várias formalidades, providências quanto à documentação, prazo de antecedência obrigatório para os proclamas, enquanto o segundo simplesmente se perfaz com base na situação fática, independe de qualquer documentação ou manifestação expressa de vontade dos companheiros.

Não se afasta, todavia, que a união estável pode ser planejada e formalizada, semelhante ao casamento, ainda que possa ocorrer apenas baseada na emoção, sem preocupação com os reflexos no âmbito patrimonial e sucessório da vida de ambos:

O amor é cego, teimoso e orgulhoso! É fruto do nosso jeito de olhar para o outro, da nossa capacidade de acreditar que ele é como nós gostaríamos que ele fosse. Ninguém pode ver o outro com as cores que o amor é capaz de pintá-lo. Assim é esse poderoso sentimento: cria e, ao mesmo tempo, transforma. (MALUF, 2012, p. 94)

Desta feita, ainda que envolvidos pelos melhores sentimentos e na certeza de que a união perdurará por anos, é recomendável a realização de um planejamento patrimonial, de modo que sejam efetivamente discutidas questóes econômicas decorrentes da união, bem como também importante é a efetivação dessas escolhas, seja no rompimento ou na sucessão. O casamento e a união estável são unióes de vidas, mas não se pode perder de vista os evidentes efeitos patrimoniais deles decorrentes, sob pena de desconforto.

A vida em sociedade, por si só, acarreta a necessidade das pessoas disporem de patrimônio, renda, para garantirem as condiçóes mínimas de dignidade previstas constitucionalmente: alimentação, vestuário, estudo, bem-estar.

Quando um casal se relaciona e resolve se unir por meio do casamento ou união estável, essa premissa da necessidade de dispor de bens e dinheiro permanece. Entretanto, a administração financeira da vida passa a ser feita em conjunto.

Independente da forma escolhida para constituição de família, o casal, para o bom desenvolvimento de sua relaçáo, deve planejar a vida em comum, estabelecendo a divisão de responsabilidade sobre as contas, definindo a maneira da constituição de patrimônio - se irão adquirir bens em conjunto ou cada qual cuidará e administrará o seu próprio patrimônio: são questôes que dão a base para a escolha do regime de bens adequado ao casal.

Deste modo, quando se fala em planejamento patrimonial e análise econômica do relacionamento conjugal, não se está a tratar apenas da possibilidade de rompimento futuro, mas também da análise e tomada de decisóes quanto ao quadro financeiro do casal e, por conseguinte, da família. Porém, falar em planejamento quando se está diante de situações que envolvam emoçóes, sentimentos que, inevitavelmente nos surpreendem, não é tarefa das mais simples: 
O amor e a morte não têm história própria. São eventos que ocorrem no tempo humano - eventos distintos, não conectados (muito menos de modo causal) com eventos "similares", a não ser na visão de instituiçóes ávidas por identificar - (por inventar) retrospectivamente essas conexóes e compreender o incompreensível.

Assim, não se pode aprender a amar, tal como não se pode aprender a morrer. E não se pode aprender a arte ilusória - inexistente, embora ardentemente desejada — de evitar suas garras e ficar fora de seu caminho. Chegado o momento, o amor e a morte atacaráo - mas não se tem a mínima ideia de quando isso acontecerá. Quando acontecer, vai pegar você desprevenido. (BAUMAN, 2004, p. 10).

É possível perceber, especialmente nos casais que estão se encaminhando para um novo casamento ou nova união, certa preocupação com as decorrências patrimoniais do relacionamento, muito pelo fato de suas experiências anteriores. Veja-se, por exemplo, o cuidado com a proteção patrimonial dos filhos nascidos antes da nova relação ou de outros parentes. (FERREIRA, 2015, p. 110).

Há, portanto, a necessidade de busca de equilíbrio entre os aspectos emocionais e econômicos do casamento ou da união estável, tendo em vista as consequências que este ato pode trazer às partes, tanto em relação a um eventual rompimento, quanto à partilha de bens advinda da sucessão por morte.

Em embargos de declaração da decisão que ora se analisa, lançou-se questão sobre o rol de herdeiros necessários na equiparação entre cônjuge e companheiro, pois em se declarando inconstitucional o art. 1.790, do Código Civil, estar-se-ia automaticamente considerando o companheiro como herdeiro necessário. (IBDFAM, 2018). O Supremo Tribunal Federal firmou posição no sentido de que a repercussão geral dizia respeito tão somente à aplicação do art. 1.829, do Código Civil, em relação às uniôes estáveis; isto é, não versava sobre rol de herdeiros necessários, de modo que não acolheu os Embargos e a decisão transitou em julgado em 04 de dezembro de 2018.

Com isso, permanece a insegurança jurídica, ao tempo em que remanesce certa esperança, já que em eventual futura análise, pode o Supremo Tribunal Federal não considerar o companheiro como herdeiro necessário e, assim, aquele que não queira que as consequências sucessórias recaiam sobre seu parceiro, poderá firmar testamento a fim de destinar seu patrimônio de acordo com sua vontade, tudo em respeito à liberdade e à autonomia privada que, neste momento, parecem retiradas da esfera jurídica dos indivíduos enlaçados pela união estável.

\section{Consideraçóes finais}


Diante das questôes ora analisadas, verifica-se que a discussão realizada por ocasião do julgamento do Recurso Extraordinário tem grande importância para o Direito, em especial, aos ramos do Direito das Famílias e das Sucessóes.

Isto porque trouxe à tona discussóes que ainda precisam ser aprofundadas, como é o caso da distinção dos institutos do casamento e da união estável. Trouxe, também, reflexóes a respeito dos princípios constitucionais da igualdade, da dignidade da pessoa humana, da liberdade e da autonomia privada, aplicados às formas de constituição de família e suas consequências patrimoniais e sucessórias.

Verificou-se que todos os Ministros concordam que o art. 1.790, do Código Civil (que versa sobre a sucessão do companheiro) não tem a melhor redação e nem mesmo contempla os direitos merecidos pelo companheiro. Por outro lado, é importante apontar que, de alguma maneira, as consequências entre casamento e união estável devem ser diferentes, até porque diferentes são os institutos. Além disso, na argumentação do voto divergente há especial alusão à necessidade de efetivação dos princípios da liberdade e da autonomia privada, com possibilidade de seu exercício pelos casais ao optarem pela uniáo estável ou casamento.

Entende-se, acompanhando o argumento do Ministro Dias Toffoli, que se há institutos diferentes e opção de escolha, é necessário que as consequências dessas escolhas sejam distintas pois, caso contrário, não faria sentido a coexistência de ambos no ordenamento jurídico.

Levando em conta que o Ministro Relator deixou aberta a possibilidade futura do legislador permitir o exercício da autonomia privada pelos companheiros que náo quiserem que sejam aplicadas as mesmas consequências sucessórias dos cônjuges a eles, é de se observar que tal possibilidade vem limitada pela imperiosa observância, pelo Ministro destacada, da equiparaçáo dos regimes sucessórios entre o casamento e a união estável como regra geral, o que restringe em demasia a livre manifestaçáo de vontade dos companheiros.

Não se pode negar que o princípio da igualdade, adotado como razão de decidir no caso em análise, tem sentido e relevância. No entanto, ao se equiparar as questóes sucessórias do casamento à união estável, aqueles casais que já haviam optado pela união estável, observando as consequências que a legislação dispunha, terão que rever seus planejamentos sucessórios ou testamentos.

Ao analisar a colisão entre os princípios constitucionais discutidos no julgamento do Recurso Extraordinário n. 878.694/MG, o Supremo Tribunal Federal entendeu que o princípio da isonomia entre cônjuges e companheiros deve prevalecer sobre os princípio da liberdade e da autonomia privada, já que, nos termos do voto vencedor, a autonomia privada estaria restrita aos regimes de bens ante a necessidade de intervenção estatal para 
equiparar os institutos como forma de preservar a igualdade e a dignidade da pessoa humana.

Tal decisão é questionável e merece reflexão, já que diante das consequências que virão a partir de referida equiparação, haverá necessidade de alterações na legislação ou, ainda, novas interpretaçóes a fim de possibilitar um efetivo exercício de liberdade de escolha entre a forma de constituição de família pelos casais.

O não pronunciamento do Supremo Tribunal Federal, em sede de Embargos de Declaração, sobre a questão de o companheiro ser considerado ou não herdeiro necessário, provoca insegurança jurídica nos relacionamentos constituídos sob uniáo estável, mormente no que tange ao planejamento patrimonial.

O que se percebe, por fim, é que independentemente da (não) decisão quanto ao rol de herdeiros necessários, a liberdade e a autonomia privada estão limitadas, na seara da uniáo estável, já que não se sabe sequer se testamento realizado retirando o direito de companheiros será válido futuramente e, ainda, não há qualquer outra possibilidade jurídica e legal de formar uma família no atual momento (seja por meio de casamento ou união estável) evitando consequências sucessórias em relação ao parceiro.

\section{Referências}

BARROSO, Luís Roberto. "Aqui, lá e em todo lugar": a dignidade humana no direito contemporâneo e no discurso transnacional. Revista dos Tribunais, vol. 919, p. 127, maio 2012.

BAUMAN, Zygmunt. Amor líquido: sobre a fragilidade dos laços humanos. Rio de Janeiro: Jorge Zahar, 2004.

CARVALHO, Dimas Messias de. Direito das famílias. 4. ed. São Paulo: Saraiva, 2015.

CRISTÓVAM, José Sérgio da Silva. Princípios Constitucionais: razoabilidade, proporcionalidade e argumentação jurídica. 2. ed. Curitiba: Juruá.

DIAS, Maria Berenice. Manual de direito das famílias. 10. ed. São Paulo: Revista dos Tribunais, 2015.

DIAS, Maria Berenice. Casar ou não casar? Dúvidas sobre questóes sucessórias. Revista Brasileira de Direito das Famílias e Sucessóes, Porto Alegre, v. 17, p.27-40, jun./jul.2009.

FERREIRA, Cristiana Sanchez Gomes. Análise econômica do divórcio: contributos da economia ao direito de família. Porto Alegre: Livraria do Advogado, 2015. 
IBDFAM. Embargos de Declaração opostos no RE 878.694/MG. Disponível em: http:// ibdfam.org.br/assets/img/upload/files/Peti\%C3\%A7\%C3\%A3o\%20Embargos.pdf. Acesso em: 27 jul. 2019.

LÔBO, Paulo. Direito civil: famílias. 5 ed. São Paulo: Saraiva, 2014.

MADALENO, Rolf. Toque pessoal da vontade do autor da herança com sucessão planejada em vida (Entrevista). Revista do Instituto Brasileiro de Direito de Família, n. 44 , abr./maio 2019.

MALUF, Adriana Caldas do Rego Freitas Dabus. Direito das famílias: amor e bioética. Rio de Janeiro: Elsevier, 2012.

PEREIRA, Rodrigo da Cunha. Família e cidadania - o novo CCB e a vacatio legis: anais do III Congresso brasileiro de direito de família. Belo Horizonte: IBDFAM/Del Rey, 2002.

VENOSA, Sílvio de Salvo. Direito civil: direito de família. 11. ed. São Paulo: Atlas, 2011. 